\section{SIERRA LEONE}

Area: 73,326 sq. $\mathrm{km}$

Population: $3,470,000$

Capital: Freetown

Head of State: Dr Siaka Probyn Stevens Minister of the Interior: Dr S. S. Banya

Sierra Leone comprises three regions and the Western Area (capitals shown in brackets):

\section{Eastern region (Kenema) Southern region (Bo)}

Northern region (Makeni) Western Area (Freetown)

\section{INTRODUCTION}

Prior to the formation of the Sierra Leone Police in 1836, the only law enforcement force in the country was the Native Constabulary. The Police was reorganized in 1861. Two years later it became a paramilitary force, under the command of an Inspector General of Police who was also the $\mathrm{CO}$ of the Freetown garrison.

The Sierra Leone Frontier Force was formed in 1890, but policy changes meant that it was absorbed into the South African Police in 1902.

\section{ORGANIZATION}

There are two police outfits in Sierra Leone, both with paramilitary capacity: the 3500-man Sierra Leone National Police Force, under army control, in charge of law enforcement in built-up areas; and the Sierra Leone Constabulary, a rural police with a personnel strength of 2000. The National Police Force is headed by a Commissioner, who is a nominated member of parliament. A force of about 250 Auxiliary Police is stationed in the diamondmining area of the Southern region.

Internal security duties are the responsibility of the army's Internal Security Unit, which has a personnel strength of some 1000 and reports to the First Vice-President's Office. There is a Special Security Department (SSD), which is also part of the Armed Forces, and deals with situations of a political nature. 